\title{
Incidence of bacterial Septicaemia in Ile-Ife Metropolis, Nigeria
}

\author{
Komolafe, A. O. ${ }^{1}$ and Adegoke, A. A. ${ }^{2^{*}}$ \\ ${ }^{1}$ Department of Medical Microbiology and Parasitology, Obafemi Awolowo University Hospital Complex, lle-Ife, \\ Nigeria \\ ${ }^{2}$ Department of Microbiology, University of Uyo, Uyo, Akwa Ibom State, Nigeria \\ E-mail: anthonyadegoke@yahoo.co.uk
}

Received 13 August 2008; received in revised form 22 October 2008; accepted 2 December 2008

\begin{abstract}
A retrospective study of septicaemia was conducted in Ile-Ife metropolis with a view to determine its incidence and changes in the predominant aetiological agents. Six hundred and fifty (650) subjects, aged from one day to seventy years and above were examined. They all had clinical features suggestive of septicaemia and were on admission at the Obafemi Awolowo University hospital Complex, Ile-Ife, Nigeria. Their blood specimens were seeded into thioglycolate and glucose broths and incubated at $37^{\circ} \mathrm{C}$ for 7 days. Subcultures were performed after 1, 2, 3, 4 and 7 days respectively. Growth (positivity) in the broths was assessed using conventional diagnostic methods namely macroscopy (visualization), Gram filming (microscopy) and culture. The bacterial isolates harvested were subjected to in-vitro antibiotic susceptibility tests using the disc diffusion method. Etiology was established in 204 out of 650 subjects indicating an incidence of $31.4 \%$. This difference in prevalence among different age groups was statistically significant $(P<0.01)$. The males $(112 / 650,17.2 \%)$ appeared to be more susceptible to septicaemia than the females $(94 / 650$, $14.5 \%)$ in all the age groups. This variation had no statistical significance $(P>0.01)$. Monomicrobial septicaemia had a higher prevalence $(92.2 \%)$ than polymicrobial septicaemia (7.8\%). Staphylococcus aureus and Escherichia coli constituted $43.8 \%$. Most of the offensive microbes were facultative anaerobes $(91.7 \%)$ while very few were strict aerobes $(6.8 \%)$ and strict anaerobes (1.5\%). The isolated anaerobes were Peptostreptococcus sp. (0.5\%) and Bacteroides fragilis $(1 \%)$. The in vitro susceptibility of the bacterial isolates to antibiotics indicated $76.4-95.6 \%$ sensitivity to vancomycin, zinnat, peflacin and fortum. However, they were $60-90 \%$ resistant to penicillin, ampicillin, tetracycline and septrin. This study confirmed the diverse nature of bacterial etiologies of septicaemia in the area; the need for the use of thioglycolate broths, first subcultures on or before $24 \mathrm{~h}$ instead of starting off for after $48 \mathrm{~h}$ of incubation, complementary application of macroscopy, Gram filming and culture including antibiotic susceptibility test as an integral part of diagnosis and management of septicaemia is hereby advocated, most especially in the developing countries of the world.
\end{abstract}

Keywords: Retrospective, Polymicrobial, Monomicrobial, Septicemia, Incidence, Antibiotic Susceptibility Pattern

\section{INTRODUCTION}

Blood is normally sterile in healthy individuals. It is the main transport mechanism connecting all different parts of the body. As it serves as a transport system for oxygen, food materials, waste products and others round the body, it can also carry microbes (Eugene et al., 1998). However, it has no normal flora and the presence of microorganism in it indicates failure of the defence mechanisms to maintain its sterility. In many cases such a failure is transitory and of no clinical importance but in others, it is serious and life threatening. Lymphoid tissue is an important part of the defence system acting as a filter to intercept potentially invasive pathogens as well as being the headquarter of the lymphocytes on which immunity is heavily dependent. This filter system is however liable to clinically significant infections by intercepted pathogen and it is also the primary target for some factors of infection (Douglas et al., 1981). The involvement of blood, lymphatic system and heart in many infections give us the knowledge of the presence of bacteria in the blood.
Various authors have reported bacteraemia immediately after incision of an abscess, tonsillectomy and tooth extraction (Fischer et al., 1941; Murry et al., 1941). Robert et al. (1997) described bacteraemia as a transitory disease in which bacteria present in the blood are usually eliminated from the vascular system by the reticulo endothelial system with no harmful effect, but in host with reduced immunity, septicaemia results. The term septicaemia is often used in describing severe bacteraemic infections or a condition in which the blood serves as a site of bacteria multiplication as well as a means of transfer of the infectious agent from one site to the other.

The clinical picture frequently present in septicaemia is that of septic shock which is recognized by a severe febrile episode with chills, fever, malaise, tachycardia mental confusion, hyperventilation and toxicity, a hypotension (drop in blood pressure) and prostration which results when circulating bacteria multiply at a rate that exceeds their removal by phagocytes. Complications include disseminated intravascular coagulation (DIC) and acute renal failure (Shanson, 1999).

\section{*Corresponding author}


The mortality rate varies between 15 and $35 \%$, depending on the age, the underlying condition and the treatment given (Shamson, 1998). Prompt recognition of septicaemia and immediate treatment based on the knowledge of the likely causative organism is essential. Septicemias which are of bacterial origin are caused by myriads of bacteria varying from one locality to another. Many studies on septicaemia in Nigeria have been on neonates and childhood and also retrospective (Dawodu et al., 1980) and there is therefore paucity of information on prospective study on septiceamia in different strata of society in Nigeria.

This research was designed to determine the incidence and changes in the predominant etiological agents in childhood and adult septicaemia in Ile-Ife, compare the occurrence of Gram positive and Gram negative bacteria in the subjects with culture - proven septicaemia, find the correlation between the yield of initial ( 2 days) subcultures and terminal ( 7 days) subcultures of the blood cultures prior to discard, determine which gender - male or female - is more prone to septicaemia and investigate the current burden and trends in the antibiotic susceptibility patterns of the bacterial isolates.

\section{MATERIALS AND METHODS}

\section{Study Population}

The subjects comprised six hundred and fifty (650) children and adults of both sexes aged between one day to 70 years having clinical features suggestive of septicaemia, who were on admission at Obafemi Awolowo University Teaching Hospitals Complex (OAUTHC), lle-Ife. Some of the clinical diagnosis was lung absess, puerperal sepsis, septic abortion, meningitis, birth asphyxia, burkitt lymphoma, postoperation fever, encephalitis etc. All patients that were already on antibiotic therapy were excluded.

\section{Sample Collection}

Blood samples $(2 \mathrm{~mL}$ from children and $10 \mathrm{~mL}$ from adults) were collected aseptically using sterile syringe and needle by venipuncture and the blood is carefully transferred into both the glucose broth (bottle 1) and thioglycollate broth (bottle II) labelled with the patient's name, identification number, date and time of collection.

\section{Bacteriological Processing of Blood Specimens}

The samples were analysed using the standard bacteriological media like blood agar, heated blood agar, mannitol salt agar, MacConkey agar, etc. All the bacterial isolates thus obtained were characterized and identified by studying their cultural and morphological features from the results of Gram staining reaction, serological and biochemical tests such as catalase, coagulase, motility, oxidase, indole, citrate utilization, urease, carbohydrate oxidation/fermentation etc described by Cowan et al (1974).

\section{Antibiotic Susceptibility Test}

The diffusion technique was employed to determine the antibiotic susceptibility pattern of the isolates to the selected antibiotics such as penicillin (li.u), ampicillin (10 $\mu \mathrm{g})$, tetracycline $(10 \mu \mathrm{g})$, streptomycin $(10 \mu \mathrm{g})$, cotrimoxazole $(25 \mu \mathrm{g})$, rocephin $(10 \mu \mathrm{g})$, zinnat $(30 \mu \mathrm{g})$, peflacin $(25 \mu \mathrm{g})$, cloxacillin $(10 \mu \mathrm{g})$, colistin $(10 \mu \mathrm{g})$ erythromycin $(10 \mu \mathrm{g})$ gentamycin $(10 \mu \mathrm{g})$ and ceftriaxone $(30 \mu \mathrm{g})$. The multi-antibiotic discs were commercially prepared by Abtek. The antibiogram was performed in accordance with standards described by the National Committee for Clinical Laboratory Standards (1987).

\section{Standardization of inoculum}

Four pure colonies of each isolate on a $24 \mathrm{~h}$ plate culture were randomly selected and inoculated into $2 \mathrm{~mL}$ of sterile peptone water broth in bijou bottles. This was incubated at $37^{\circ} \mathrm{C}$ for $6 \mathrm{~h}$ and the turbidity was adjusted by serial dilution in phosphate buffer saline $(\mathrm{pH} \mathrm{7.2)}$ to match an opacity tube containing $0.5 \mathrm{~mL}$ of $1 \%$ barium chloride in $1 \%$ suplhuric acid (a Mc Farlands 0.5 barium sulphate standard containing $10^{5} \mathrm{cfu} / \mathrm{mL}$ of the inoculums). One milliliter (1 $\mathrm{mL})$ of the culture dilution (bacteria suspension) was transferred into a well dried surface of diagnostic sensitivity test agar (DST) medium and titled to spread evenly over the entire surface of the agar plate. The excess fluid was drained off and dried within 5 min multi-antibiotic discs were then placed on the surface of the inoculated plate and incubated aerobically at $37^{\circ} \mathrm{C}$ for 18 to $24 \mathrm{~h}$ (over-night). S. aureus NCTC 6751 and E. coli NCTC 10418 were used as control organisms for the sensitivity test. The diameter of the zone of inhibition was measured in millimeter.

The result of each antimicrobial agent tested was reported as susceptible or resistant when the test organism was compared with the control. Zone diameter equal to wider than or not more than $6 \mathrm{~mm}$ smaller than the control was regarded as sensitive. No zone of inhibition or a zone diameter of $12 \mathrm{~mm}$ or less was regarded as resistant.

\section{RESULTS}

A total of 650 patients who fulfilled the criteria for diagnosis of presumed septicaemia were bacteriologically screened. These included 33 (5.0\%) neonates, 109 (16.8\%) children and 508 (78.25\%) adults. An etiology could be established in 204 subjects indicating incidence of $31.4 \%$. In total, blood samples of $420(64.6 \%)$ patients were bacteriologically sterile and 26 $(4 \%)$ of their blood samples grew contaminants. No growth in the negative (sterility) controls of the two blood culture broths while there was a profuse growth in the positive controls. 
Figure 1 show the age and gender prevalence of septicaemia among the culture-proven patients in Ile-Ife. It occurs in all age groups. Children in age bracket of 0 10 years were observed to be most vulnerable (18.1\%) and there was a dramatic (sharp) reduction in the rate as the subjects advance in age. Nevertheless, the lowest $(0.5 \%)$ prevalence was observed among patients in age group of 51 - 60 years. Although males were more $(112 / 650,17.2 \%)$ prone to this disease than females $(94 / 650,14.5 \%)$ in all age groups except in age group of 51 years and above. There was no statistically significant variation in the prevalence of septicaemia according to gender and age of the subjects examined.

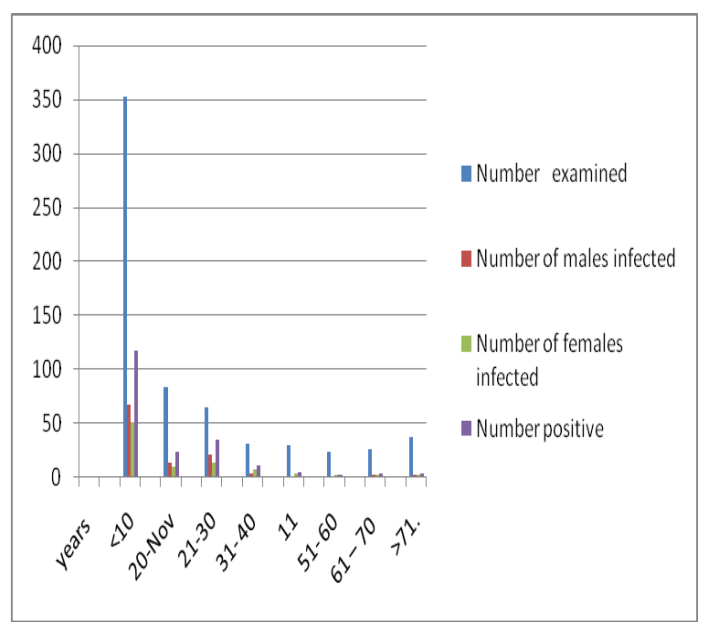

Figure 1: Prevalence of culture - proven septicaemia according to Age and gender of the subjects .

The occurrence of neonatal septicaemia among the 33 culture positive neonates in relation to age and sex distribution of the study population is shown in Figure 1. The infection has the highest $(78.8 \%)$ occurrence in the first week of life. There was apparent dramatic fall in the frequency with age increase. Surprisingly and comparatively, more male neonates $(57.6 \%)$ than females $(42.4 \%)$ were positive.

The distribution of microbial isolates from blood of the subjects with clinically suspected septicaemia is shown in Table 1. The detailed aetiology of the 204 isolates is as follows: One hundred and ten $53.9 \%$ of the organisms were gram-positive, 93 (45.5\%) were gramnegative and $1(0.5 \%)$ was Candida albicans, Staphylococci and Klebsiella sp. were the predominant Gram positive and Gram negative organisms, all together accounting for $51.5 \%(105 / 204)$ and $17.1 \%$ (35/204) of the isolates respectively. Other common Gram negative bacterial isolates in descending order of frequency included E. coli (9.8\%), Pseudomonas sp. (6.9\%), Salmonella sp. (7.45\%), Proteus sp. (1.5\%), Citrobacter sp. (1.5\%), Bacteroides fragillis (1\%), $H$. influenzae $(0.5 \%)$ and whereas the Gram positive bacteria included $S$. albus (7.8\%), S. faecalis $1 \%$, Streptococcus pneumoniae (0.5\%), S. pyogenes and Peptostretococus sp.

In culture-positive adults and children, the cause of septicaema was majorly monomicroial in 188/204 (92.2\%) cases and polymicrobial in 16/204 (7.8\%) cases. In polymicrobial septicaemia, association of two organisms was observed in 16 cases. Gram positive organisms were present in $15(93.8 \%)$ of these cultures. These were either association between one Gram positive organisms or a Gram negative organism. A combination of two Gram negative bacteria was observed in 1/15 (6.3\%) cases and combination of Gram positive bacteria was nil $(0 \%)$ while that of Gram positive and Gram negative bacteria was (14/16) $87.5 \%$ cases. In one adult, Gram positive organism was grown along with $C$. albicans (Table 2).

In Table 3, we see that facultative anaerobes account for the greatest $187(91.7 \%)$ causative agents of septicaemia, followed by strict aerobes 14 (6.8\%) and strict anaerobes $3(1.5 \%)$ respectively from the overall 204 isolates. The anaerobes encountered were Bacterioides fragilis 2 (66. 7\%) and Peptostreptococcus sp. $1(33.3 \%)$.

Table 3 shows the reflection of the comparative efficiency of two blood culture broths - glucose and thioglycollate broths that are routinely used in most clinical laboratories in Nigeria to isolate microbes from the blood streams of the infected host. Thioglycollate broth has a higher success rate $(100 \%)$ than glucose broth $(91.7 \%)$.

The effect of the duration of incubation on the yield (harvest) of microorganisms from blood stream of subjects with clinically suspected septicemia is shown in Table 4. This investigation was conducted at a constant incubation temperature of $37^{\circ} \mathrm{C}$ aerobically and anaerobically and in thioglycollate broth. Subcultures performed after 1, 2, 4, and 7 days of incubation after receipt yield rates of $68 \%, 87 \%$ and $100 \%$, respectively.

Three conventional diagnostic methods for the detection of positive blood culture at constant temperature of $37^{\circ} \mathrm{C}$, incubation period of 4 days in a glucose broth were assessed and the results shown in Table 4. Culture was the most sensitive detector of microorganisms among the 3 procedures considered, followed by Gram filming (microscopy) and then macroscopy (visualization) with sensitivity rate of $31.4 \%$, $25.4 \%$ and $21.2 \%$ respectively. 
Table I: Frequency (distribution) and gram reactions of aetiological agents of culture-proven septicaema

\begin{tabular}{|c|c|c|c|}
\hline $\begin{array}{l}\text { Gram } \\
\text { Reaction }\end{array}$ & Blood Culture isolates & No. of isolates & $\%$ of the isolates \\
\hline \multirow[t]{7}{*}{ Positive } & Staphylococcus. aureus & 89 & 43.6 \\
\hline & $\begin{array}{l}\text { S. albus (+other coagulase } \\
\text { negative Staphylococcus) }\end{array}$ & 16 & 7.8 \\
\hline & Streptococcus faecalis & 2 & 1.0 \\
\hline & S. pneumoniae & 1 & 0.5 \\
\hline & S. pyogenes & 1 & 0.5 \\
\hline & Peptostreptococcus sp. & 1 & 0.5 \\
\hline & Total & 110 & 53.9 \\
\hline \multirow[t]{15}{*}{ Negative } & Klebsiella sp. & 35 & 17.1 \\
\hline & E. coli & 20 & 9.8 \\
\hline & Pseudomonas sp. & 14 & 6.9 \\
\hline & Salmonella typhi & 10 & 4.9 \\
\hline & Salmonella parataphi & 4 & 2. 0 \\
\hline & Salmonella sp. & 1 & 0.5 \\
\hline & Proteus mirabilis & 2 & 1.0 \\
\hline & P. morgani & 1 & 1.0 \\
\hline & Citrobacter freundi & 2 & 0.5 \\
\hline & C. diversus & $\overline{1}$ & 0.5 \\
\hline & Haemohilus influenzae & 1 & 0.5 \\
\hline & Bacteroides fragilis & 2 & 1.0 \\
\hline & Klebsiella sp. & 35 & 17. 1 \\
\hline & E. coli & 20 & 9.8 \\
\hline & Total & 93 & 45.5 \\
\hline \multirow[t]{2}{*}{ Yeast } & C. albicans & 1 & 0.5 \\
\hline & Grand Total & 204 & 100 \\
\hline
\end{tabular}

Table 2: Polymicrobial aetiology of septiceamia.

\begin{tabular}{lcl}
\hline Association of organisms & $\begin{array}{c}\text { No. of } \\
\text { cases }\end{array}$ & Frequency (\%) \\
\hline E. coli and Staphylococcus aureus & 7 & 43.8 \\
Klebsiella sp. and S. aureus & 3 & 18.8 \\
Klebsiella sp. and S. aureus & 2 & $12.5 \%$ \\
E. coli and Streptococcus faecalis & 1 & 6.2 \\
Staphylococcus aureus and C. albicans & 1 & 6.2 \\
Bacteriodes fragilis and Staphylococcus aureus & 1 & 6.2 \\
\hline Total & 16 & 100 \\
\hline
\end{tabular}

Table 3: Evaluation of the efficiency of two blood culture broths in laboratory diagnosis of septicaemia

\begin{tabular}{lllll}
\hline $\begin{array}{l}\text { Gram reaction } \\
\text { of bacterial } \\
\text { isolates }\end{array}$ & $\begin{array}{l}\text { Growth in } \\
\text { glucose } \\
\text { broth } \\
\text { No. +ve }\end{array}$ & Frequency (\%) & $\begin{array}{l}\text { Growth in } \\
\text { Thioglycollate } \\
\text { broth } \\
\text { No. + ve }\end{array}$ & Frequency (\%) \\
\hline Gram + ve & 96 & $47 \%$ & 110 & $54 \%$ \\
$\begin{array}{l}\text { Gram - ve } \\
\text { Yeast }\end{array}$ & 90 & 44.1 & 93 & 45.6 \\
\hline Total & 1 & 0.5 & 1 & 0.5 \\
\hline
\end{tabular}

(Temperature $=37^{\circ} \mathrm{C}$, Incubation period $=7$ days, $\mathrm{N}=204$ ). 
Table 4: Evaluation of the effect of duration of incubation on the yield of bacteria from blood culture broth for laboratory diagnosis of septicaemia

\begin{tabular}{lllll}
\hline $\begin{array}{l}\text { Organisms } \\
\text { lsolated from } \\
\text { thioglycollate } \\
\text { broth }\end{array}$ & $\mathbf{1}$ & $\mathbf{2}$ & $\mathbf{4}$ & $\mathbf{7}$ \\
\hline Gram + ve & 47 & 78 & 100 & 100 \\
$\begin{array}{l}\text { Gram - ve } \\
\text { Mean }\end{array}$ & 90 & 96 & 100 & 100 \\
positive on & 68.5 & 87 & 100 & 100 \\
each day & & & &
\end{tabular}

$\left(\right.$ Temperature $=37^{\circ} \mathrm{C}$, Broth $=$ Thioglycollate, Gram positive organisms $=111$, Gram negative organisms $=$ 92)

Table 5 represent the result antimicrobial susceptibility tests of the Gram positive bacterial isolates harvested from the patients' blood. Seventy to ninety (70 - $90 \%$ ) percent of $S$. aureus were resistant to the commonly used antibiotics including penicillin, amplicillin, tetracycline and cotrimoxazole. More than $80 \%$ of $S$. aureus isolates were sensitive to gentamycin, fortum, rocephin, peflacin and vancomycin. S. albus exhibited higher antibiotic resistance to the commonly used antibiotics. The antibiotic susceptibility patterns of the 16 albus strains were penicillin $0 \%$, ampicillin $0 \%$, tetracycline $12.5 \%$ and cloxacillin $43.8 \%$, erythromycin $56.3 \%$, chloramphenicol $31.3 \%$, streptomycin $43.0 \%$ and cotrimoxazole $18.8 \%$ while $60-90 \%$ of them were susceptible to gentamycin and vancomycin, fortum, rocephin, zinnat and peflacin. Streptococcus pneumoniae and S. pyogenes were 100\% sensitive to all antibiotics employed such as penicillin, ampicillin, tetracycline cloxacillin, erythromycin, chloramphenicol, cotrimoxzazole, vancomycin, fortum, rocephin, zinnat and peflacin except two aminogycosides - streptomycin and gentamycin in to which they were resistant. In sum, all the Gram positive isolates had mean antibiotic sensitivity pattern ranging between $10-87 \%$ to all the antibiotics used.

Table 6 shows the antibiotic profile of Gram negative bacteria isolates. Ninety to one hundred percent (90 $100 \%$ ) of Klebsiella sp. the predominant Gram negative bacilli, isolated were sensitive to rocephin, peflacin, colistin and fortum and $10-40 \%$ resistant to ampcillin, tetracycline and cotrimoxazole. Fifty seven and sixty three (57 and $63 \%$ ) percents of them were sensitive to streptomycin and gentamycin respectively. Eighty five to ninety five percent $85-95 \%$ ) of $E$. coli isolates, the second highest number of isolates, were sensitive to gentamcycin, colistin, fortum, rocephin and peflacin whereas they were $50-65 \%$ sensitive to cotrimoxazole, tetracycline and chloramphenicol respectively and $10 \%$ to ampicillin. Salmonella sp. isolates exhibited high degree level of sensitivity to antibiotics eighty to one hundred percent. Eighty to hundred percent $(80-100 \%)$ of them were sensitive to tetracycline, gentamycin, chloramphenicol, fortum, rocephin, zinnat, peflacin and colistin. Of the 14 Pseudomonas sp. isolates $92-100 \%$ was susceptible to gentamycin, fortum, peflacin and colistin. However, they were $100 \%$ resistant to ampicillin, cotrimoxazole, chloramphenicol and zinnacet. Haemophilus influenzae (1) was $100 \%$ susceptible to cotrimoxazole, streptomycin, gentanycin, fortum, rocephin, zinnat, peflacin, chlorampenicol and colistin and resistant to ampicillin and tetracycline. In summary, all the Gram negative bacilli isolates had an antibiotic susceptibility level ranging from $19.8-95 \%$ for all the antibiotics employed.

Table 7 shows the antibiotics susceptibility patterns of anaerobic bacterial isolates. All the 3 isolates (100\%) were sensitive to fortum, rocephine, zinnat, peflacin and metronidazole but Bacteroides sp. were 100\% resistant to penicillin and colistin.

All the bacterial isolates were $(80-100 \%)$ susceptible to newly discovered 3rd generation antibiotics such as peflacin, rocephin , fortum and zinnat and moderately $(43-60 \%)$ to second generation like cloxacillin, erythromycin, cotrimoxazole, chloramphenicol and few $(0-12.5 \%)$ to first generation ones such as penicillin, tetracycline and ampicillin.

\section{DISCUSSION}

The findings of this study revealed that Septicemia still remains the major killer disease in Nigeria (Eugene, 1998). Although its incidence of $31.4 \%$ found in this study is higher than the $26 \%$ reported by Akuse et al. in 1984 at Ibadan among the neonates, it fell within the range of 15$35 \%$ reported by Shanson in 1999. This study has established that the disease affects all age groups but it was noticeable that neonates, children and teenagers were more vulnerable than adults as persons between years of 0-20 years were most infected. This vulnerability was most prominent, pronounced and apparent among the neonates because they accounted for the majority $(16.2 \%)$ of the patients that had culture-proven septiceamia in this study. It was observed that septicaemia was most prevalent in the first week of life and reduced remarkably with age increase (Table 1). This difference in age distribution of the infection was statistically significant $(P<O)$. The higher occurrence in childhood septicaemia has been reported from different parts of Nigeria (Akuse et al., 1998; Akpede et al., 1996, Ako-Nai et al., 1999, Angyo et al., 2001; Owa et al., 1988; Olusanya et al., 1991). The high occurrence of neonatal septiceamia in lle-Ife may probably be adduced to their low immune response, socio-economic status of the parents, poor hygiene practices, bottle feeding and high incidence of delivery at home. An additional effect of their low socio-economic status is exhibited by the inability of their parents to pay the hospital fees charged for delivery; consequently they deliver at home, churches, maternity centre or herbalist shrines where there are no proper midwifery facilities. Infections of neonates may be due to contamination as a result of poor hospital hygiene and 
Malaysian Journal of Microbiology, Vol 4(2) 2008, pp. 51- 61

Table 5: Antibiogram of the Gram positive bacteria

\begin{tabular}{|c|c|c|c|c|c|c|c|c|c|c|c|c|c|c|c|}
\hline $\begin{array}{l}\text { Microbial } \\
\text { isolates }\end{array}$ & $\begin{array}{l}\text { No. } \\
\text { tested }\end{array}$ & $\begin{array}{l}\text { PEN } \\
\text { No. } \\
\%\end{array}$ & $\begin{array}{l}\text { AP } \\
\text { No. } \%\end{array}$ & $\begin{array}{l}\text { TE } \\
\text { No. \% }\end{array}$ & $\begin{array}{l}\text { CLX } \\
\text { No. \% }\end{array}$ & $\begin{array}{l}\text { ERY } \\
\text { No. \% }\end{array}$ & $\begin{array}{l}\text { CHL } \\
\text { No. } \\
\%\end{array}$ & $\begin{array}{l}\text { VAN } \\
\text { No. } \\
\%\end{array}$ & $\begin{array}{l}\text { STR } \\
\text { No. \% }\end{array}$ & $\begin{array}{l}\text { GEN } \\
\text { No. \% }\end{array}$ & $\begin{array}{l}\text { COT } \\
\text { No. } \%\end{array}$ & $\begin{array}{l}\text { CAZ } \\
\text { No. } \%\end{array}$ & $\begin{array}{l}\text { CRO } \\
\text { No. \% }\end{array}$ & $\begin{array}{l}\text { CXM } \\
\text { No. \% }\end{array}$ & $\begin{array}{l}\text { PEF } \\
\text { No. } \\
\%\end{array}$ \\
\hline S. aureus & 89 & $\begin{array}{l}8 . \\
(8.9)\end{array}$ & $\begin{array}{l}13 \\
(14.6)\end{array}$ & $\begin{array}{l}36 \\
(40.4)\end{array}$ & $\begin{array}{l}47 \\
(52.8)\end{array}$ & $\begin{array}{l}65 \\
(73.0)\end{array}$ & $\begin{array}{l}50 \\
(56.2)\end{array}$ & $\begin{array}{l}84 \\
(94.4)\end{array}$ & $\begin{array}{l}35 \\
(39.3)\end{array}$ & $\begin{array}{l}73 . \\
(82.0)\end{array}$ & $\begin{array}{l}24 . \\
(26.9)\end{array}$ & $\begin{array}{l}75 \\
(84.3)\end{array}$ & $\begin{array}{l}79 \\
(88.8)\end{array}$ & $\begin{array}{l}69 \\
(77.5)\end{array}$ & $\begin{array}{l}79 \\
(88.8)\end{array}$ \\
\hline S. albus & 10 & $\begin{array}{l}\text { (0.J) } \\
(0)\end{array}$ & $\begin{array}{l}0 \\
(0)\end{array}$ & $\begin{array}{l}2 \\
(12.5)\end{array}$ & $\begin{array}{l}7 . \\
(43.8)\end{array}$ & $\begin{array}{l}9 . \\
(56.3)\end{array}$ & $\begin{array}{l}5 . \\
(313)\end{array}$ & 15.(93.8) & $\begin{array}{l}7 \\
(43.8)\end{array}$ & $\begin{array}{l}10 . \\
(62.5)\end{array}$ & $\begin{array}{l}3 . \\
(18.8)\end{array}$ & $\begin{array}{l}11 . \\
(68.8)\end{array}$ & $\begin{array}{l}12 . \\
(75)\end{array}$ & $\begin{array}{l}10 . \\
(62.5)\end{array}$ & $\begin{array}{l}12 . \\
(75)\end{array}$ \\
\hline $\begin{array}{l}\text { Strept. } \\
\text { faecalis }\end{array}$ & 2 & $\begin{array}{l}0 \\
(0)\end{array}$ & $\begin{array}{l}1 \\
(50)\end{array}$ & $\begin{array}{l}2 \\
(100)\end{array}$ & $\begin{array}{l}2 \\
(100)\end{array}$ & $\begin{array}{l}2 \\
(100)\end{array}$ & $\begin{array}{l}1 \\
(50)\end{array}$ & $\begin{array}{l}2 \\
(100)\end{array}$ & $\begin{array}{l}0 \\
(0)\end{array}$ & $\begin{array}{l}1 \\
(50)\end{array}$ & $\begin{array}{l}0 \\
(0)\end{array}$ & $\begin{array}{l}2 \\
(100)\end{array}$ & $\begin{array}{l}2 \\
(100)\end{array}$ & $\begin{array}{l}2 \\
(100)\end{array}$ & $\begin{array}{l}2 \\
(100)\end{array}$ \\
\hline $\begin{array}{l}\text { Strept. } \\
\text { Pneumoniae }\end{array}$ & 1 & $\begin{array}{l}1 \\
(100)\end{array}$ & $\begin{array}{l}1 \\
(100)\end{array}$ & $\begin{array}{l}1 \\
(100)\end{array}$ & $\begin{array}{l}1 \\
(100)\end{array}$ & $\begin{array}{l}1 \\
(100)\end{array}$ & $\begin{array}{l}1 \\
(100)\end{array}$ & $\begin{array}{l}1 \\
(100)\end{array}$ & $\begin{array}{l}0 \\
(0)\end{array}$ & & $\begin{array}{l}1 \\
(100)\end{array}$ & $\begin{array}{l}1 \\
(100)\end{array}$ & $\begin{array}{l}1 \\
(100)\end{array}$ & $\begin{array}{l}1 \\
(100)\end{array}$ & $\begin{array}{l}1 \\
(100)\end{array}$ \\
\hline $\begin{array}{l}\text { Strept. } \\
\text { pyogenes }\end{array}$ & 1 & $\begin{array}{l}1 \\
(100)\end{array}$ & $\begin{array}{l}1 \\
(100)\end{array}$ & $\begin{array}{l}1 \\
(100)\end{array}$ & $\begin{array}{l}1 \\
(100)\end{array}$ & $\begin{array}{l}1 \\
(100)\end{array}$ & $\begin{array}{l}1 \\
(100)\end{array}$ & $\begin{array}{l}1 \\
(100)\end{array}$ & 0 & (0) & $\begin{array}{l}1 \\
(100)\end{array}$ & $\begin{array}{l}1 \\
(100)\end{array}$ & $\begin{array}{l}1 \\
(100)\end{array}$ & $\begin{array}{l}1 \\
(100)\end{array}$ & $\begin{array}{l}1 \\
(100)\end{array}$ \\
\hline $\begin{array}{l}\text { Peptostre- } \\
\text { ptococcus }\end{array}$ & 1 & $\begin{array}{l}1 \\
(100)\end{array}$ & $\begin{array}{l}1 \\
(100)\end{array}$ & $\begin{array}{l}1 \\
(100)\end{array}$ & $\begin{array}{l}1 \\
(100)\end{array}$ & $\begin{array}{l}1 \\
(100)\end{array}$ & $\begin{array}{l}1 \\
(100)\end{array}$ & $\begin{array}{l}0 \\
(0)\end{array}$ & $\begin{array}{l}0 \\
(0)\end{array}$ & $\begin{array}{l}0 \\
(0)\end{array}$ & $\begin{array}{l}1 \\
(100)\end{array}$ & $\begin{array}{l}1 \\
(100)\end{array}$ & $\begin{array}{l}1 \\
(100)\end{array}$ & $\begin{array}{l}1 \\
(100)\end{array}$ & $\begin{array}{l}1 \\
(100)\end{array}$ \\
\hline Total & 110 & $\begin{array}{l}11 \\
(10)\end{array}$ & $\begin{array}{l}17 \\
(15.5)\end{array}$ & $\begin{array}{l}43 \\
(39.1)\end{array}$ & $\begin{array}{l}59 \\
(53.6)\end{array}$ & $\begin{array}{l}79 \\
(72.0)\end{array}$ & $\begin{array}{l}59 \\
(54)\end{array}$ & $\begin{array}{l}103 \\
(94)\end{array}$ & $\begin{array}{l}42 \\
(38.1)\end{array}$ & $\begin{array}{l}84 \\
(76.4)\end{array}$ & $\begin{array}{l}30 \\
(27.3)\end{array}$ & $\begin{array}{l}91 \\
(827)\end{array}$ & $\begin{array}{l}96 \\
(87.2)\end{array}$ & $\begin{array}{l}84 \\
(76 . \\
4)\end{array}$ & $\begin{array}{l}96 \\
(87.3)\end{array}$ \\
\hline
\end{tabular}

Isolates number and $\%$ sensitive

$\begin{array}{ll}\text { PEN } \quad- & \text { penicillin } \\ \text { AP }- & \text { ampicillin } \\ \text { TE }- & \text { tetracycline } \\ \text { CLX - } & \text { cloxacillin } \\ \text { ERY }- & \text { erythromycin }\end{array}$

CAL - chloramphenicol

VAN - vancomycin

STR. streptomycin

GEN- gentamycin

COT - cotrimoxazole .
$\mathrm{CAZ}$ - fortum

$\mathrm{CRO}$ - rocephin

CXM - zinnat

PEF - peflacin 
Malaysian Journal of Microbiology, Vol 4(2) 2008, pp. 51- 61

Table 6: Antibiogram of the Gram negative bacteria

\begin{tabular}{|c|c|c|c|c|c|c|c|c|c|c|c|c|}
\hline Isolates & $\begin{array}{l}\text { No. } \\
\text { tested }\end{array}$ & AP & TE & CHL & COT & STR & GEN & COL & CAZ & CRO & CXM & PEF . \\
\hline Klebsiella sp. & 35 & 5. (14.2) & $\begin{array}{l}16 \\
(45.7)\end{array}$ & $\begin{array}{l}24 \\
(68.6)\end{array}$ & $\begin{array}{l}10 \\
(28.6)\end{array}$ & $\begin{array}{l}20 \\
(57.1)\end{array}$ & $\begin{array}{l}22 \\
(62.9)\end{array}$ & $\begin{array}{l}34 \\
(97.1)\end{array}$ & $35(100)$ & $\begin{array}{l}32 \\
(91.4)\end{array}$ & $\begin{array}{l}23 \\
(65.7)\end{array}$ & $\begin{array}{l}31 \\
(88.6)\end{array}$ \\
\hline E. coli & 20 & $\begin{array}{l}2 \\
(10)\end{array}$ & $\begin{array}{l}12 \\
(60)\end{array}$ & $\begin{array}{l}13 \\
(65)\end{array}$ & $\begin{array}{l}7 \\
(35)\end{array}$ & $\begin{array}{l}10 \\
(50)\end{array}$ & $\begin{array}{l}17 \\
(85)\end{array}$ & $\begin{array}{l}19 \\
(95)\end{array}$ & $\begin{array}{l}18 \\
(90)\end{array}$ & $18(90)$ & $\begin{array}{l}15 \\
(75)\end{array}$ & $\begin{array}{l}18 \\
(90)\end{array}$ \\
\hline $\begin{array}{l}\text { Salmonella } \\
\text { sp. }\end{array}$ & 5 & $\begin{array}{l}4 \\
(80)\end{array}$ & $\begin{array}{l}4 \\
(80)\end{array}$ & $\begin{array}{l}2 \\
(40)\end{array}$ & 2 & 4 & $\begin{array}{l}4 \\
(80)\end{array}$ & $\begin{array}{l}5 \\
(100)\end{array}$ & $\begin{array}{l}5 \\
(100)\end{array}$ & $\begin{array}{l}5 \\
(100)\end{array}$ & $\begin{array}{l}5 \\
(100)\end{array}$ & $\begin{array}{l}5 \\
(100)\end{array}$ \\
\hline $\begin{array}{l}\text { Salmonella } \\
\text { typhi }\end{array}$ & 10 & $\begin{array}{l}4 \\
(40)\end{array}$ & $\begin{array}{l}8 \\
(80)\end{array}$ & $\begin{array}{l}8 \\
(80)\end{array}$ & $\begin{array}{l}7 \\
(70)\end{array}$ & & $\begin{array}{l}9 \\
(90)\end{array}$ & $\begin{array}{l}10 \\
(100)\end{array}$ & $\begin{array}{l}9 \\
(90)\end{array}$ & $\begin{array}{l}9 \\
(90)\end{array}$ & $\begin{array}{l}9 \\
(90)\end{array}$ & $\begin{array}{l}9 \\
(90)\end{array}$ \\
\hline Proteus sp. & 3 & $\begin{array}{l}1 \\
\text { (33.3) }\end{array}$ & $\begin{array}{l}3 \\
(100)\end{array}$ & 1 (33.3) & 1 (33.3) & $2(66.7)$ & (1 33.3) & $\begin{array}{l}0 \\
(0)\end{array}$ & $\begin{array}{l}3 \\
(100)\end{array}$ & $\begin{array}{l}3 \\
(100)\end{array}$ & $\begin{array}{l}3 \\
(100)\end{array}$ & $\begin{array}{l}3 \\
(100)\end{array}$ \\
\hline $\begin{array}{l}\text { Pseudomonas } \\
\text { sp. }\end{array}$ & 14 & $\begin{array}{l}0 \\
(0)\end{array}$ & $\begin{array}{l}3 \\
(2.4)\end{array}$ & $\begin{array}{l}0 \\
(0)\end{array}$ & $\begin{array}{l}0 \\
(0)\end{array}$ & $\begin{array}{l}3 \\
(21.4)\end{array}$ & $\begin{array}{l}13 \\
(92.8)\end{array}$ & $\begin{array}{l}13 \\
(92.8)\end{array}$ & $\begin{array}{l}13 \\
(98.2)\end{array}$ & $14(100)$ & $\begin{array}{l}0 \\
(0)\end{array}$ & $\begin{array}{l}13 \\
(92.8)\end{array}$ \\
\hline Citrobacter sp. & 3 & 1 (33.3) & 1 (33.3) & $2(66.7)$ & 1 (33.3) & 2. $(66.7)$ & $\begin{array}{l}2 \\
(60.7)\end{array}$ & 2. $(66.7)$ & $\begin{array}{l}3 \\
(100)\end{array}$ & $\begin{array}{l}2 . \\
(66.7)\end{array}$ & $\begin{array}{l}3 \\
(100)\end{array}$ & $\begin{array}{l}3 \\
(100)\end{array}$ \\
\hline H. Influenzae & 1 & $\begin{array}{l}1 \\
(100)\end{array}$ & $\begin{array}{l}1 \\
(100)\end{array}$ & $\begin{array}{l}1 \\
(100)\end{array}$ & $\begin{array}{l}1 \\
(100)\end{array}$ & $\begin{array}{l}1 \\
(100)\end{array}$ & $(100)$ & $\begin{array}{l}1 \\
(100)\end{array}$ & $\begin{array}{l}1 \\
(100)\end{array}$ & $(100)$ & $(100)$ & $\begin{array}{l}1 \\
(100)\end{array}$ \\
\hline Total & 91 & $\begin{array}{l}18 \\
(19.8)\end{array}$ & $\begin{array}{l}48 . \\
(52.7)\end{array}$ & $\begin{array}{l}51 \\
(56.0)\end{array}$ & $\begin{array}{l}29 \\
(31.9)\end{array}$ & $\begin{array}{l}49 \\
(53.8)\end{array}$ & $\begin{array}{l}69 \\
(75.8)\end{array}$ & $\begin{array}{l}85 \\
(92.3)\end{array}$ & $\begin{array}{l}87 \\
(95.6)\end{array}$ & $\begin{array}{l}84 \\
(92.3)\end{array}$ & $\begin{array}{l}59 \\
(64.8)\end{array}$ & $\begin{array}{l}84 \\
(92.3)\end{array}$ \\
\hline
\end{tabular}

The table shows the number and (\%) of sensitive isolates.

$$
\begin{aligned}
& \text { AP - ampicillin } \\
& \text { TE - tetracycline } \\
& \text { CHL - chloramphenicol } \\
& \text { COT - cotrimoxazole } \\
& \text { STR - streptomycin }
\end{aligned}
$$$$
\mathrm{COL} \text { - colistin }
$$$$
\mathrm{CAZ} \text { - fortum }
$$$$
\mathrm{CRN} \text { - rocephin }
$$$$
\text { CXM - zinnat }
$$$$
\mathrm{PEF} \text { - peflacin }
$$ 
Malaysian Journal of Microbiology, Vol 4(2) 2008, pp. 51- 61

Table 7: Antibiogram of anaerobic isolates

\begin{tabular}{|c|c|c|c|c|c|c|c|c|c|c|c|c|c|c|c|}
\hline Isolates & $\begin{array}{l}\text { No. } \\
\text { tested }\end{array}$ & PEN & AP & TE & CLX & ERY & CHL & MET & GEN & STR & CAZ & CRO & CXM & PEF & COL \\
\hline $\begin{array}{l}\text { Bacteroides } \\
\text { fragilis } \\
\text { Pepstrepto- } \\
\text { coccus sp. }\end{array}$ & 2 & $\begin{array}{l}0 \\
(0) \\
1 \\
(100)\end{array}$ & $\begin{array}{l}1 \\
(50) \\
1 \\
(100)\end{array}$ & $\begin{array}{l}1 \\
(50) \\
1 \\
(100) \\
\end{array}$ & $\begin{array}{l}0 \\
(0) \\
1 \\
(100)\end{array}$ & $\begin{array}{l}0 \\
(0) \\
1 \\
(100)\end{array}$ & $\begin{array}{l}0 \\
(0) \\
1 \\
(100)\end{array}$ & $\begin{array}{l}2 \\
(100) \\
1 \\
(100)\end{array}$ & $\begin{array}{l}2 \\
(100) \\
1 \\
(100)\end{array}$ & $\begin{array}{l}2 \\
(100) \\
1 \\
(100) \\
\end{array}$ & $\begin{array}{l}2 \\
(100) \\
1 \\
(100)\end{array}$ & $\begin{array}{l}2 \\
(100) \\
1 \\
(100)\end{array}$ & $\begin{array}{l}2 \\
(100) \\
1 \\
(100)\end{array}$ & $\begin{array}{l}2 \\
(100) \\
1 \\
(100)\end{array}$ & $\begin{array}{l}0 \\
(0) \\
0 \\
(0) \\
\end{array}$ \\
\hline Total & 3 & $\begin{array}{l}1 \\
\text { (33.3) }\end{array}$ & $\begin{array}{l}2 \\
(66.7)\end{array}$ & $\begin{array}{l}2 \\
(66.7)\end{array}$ & $\begin{array}{l}1 \\
\text { (33.3) }\end{array}$ & $\begin{array}{l}1 \\
\text { (33.3) }\end{array}$ & $\begin{array}{l}1 \\
\text { (33.3) }\end{array}$ & $\begin{array}{l}3 \\
(100)\end{array}$ & $\begin{array}{l}3 \\
(100)\end{array}$ & $\begin{array}{l}3 \\
(100) \\
\end{array}$ & $\begin{array}{l}3 \\
(100)\end{array}$ & $\begin{array}{l}3 \\
(100)\end{array}$ & $\begin{array}{l}3 \\
(100)\end{array}$ & $\begin{array}{l}3 \\
(100)\end{array}$ & $0(0$ \\
\hline PEN & \multicolumn{3}{|c|}{ - penicillin } & & STR & \multicolumn{2}{|c|}{ - streptomycin } & & & & & & & & \\
\hline AP & \multicolumn{3}{|c|}{ - ampicillin } & & CAZ & \multicolumn{2}{|c|}{ - fortum } & & & & & & & & \\
\hline TR & \multicolumn{3}{|c|}{ - Tetracycline } & & CRO & \multicolumn{2}{|l|}{ - rocephin } & & & & & & & & \\
\hline CLX & \multicolumn{3}{|c|}{ cloxacillin } & & CXM & \multicolumn{2}{|l|}{ - zinnat } & & & & & & & & \\
\hline ERY- & \multicolumn{3}{|c|}{ erythromycin } & & PEF & \multicolumn{2}{|l|}{ - peflacin } & & & & & & & & \\
\hline $\mathrm{CHL}$ & \multicolumn{3}{|c|}{ chloramphenicol } & & $\mathrm{COL}$ & \multicolumn{2}{|l|}{ - colistin } & & & & & & & & \\
\hline GEN & \multicolumn{3}{|c|}{ gentamycin } & & MET & \multicolumn{2}{|c|}{-metronidazole } & & & & & & & & \\
\hline
\end{tabular}


inadequate hand - washing by staff, impairment of host principal effect of low socio-economic status is the inability of the indigent mothers to maintain successful lactation as it is necessary for the mother to be mentally and physically healthy (Beischer et al., 1979).

There was no statistically significant difference in gender variation in septicaemia, it is interesting to notice that males has a higher prevalence level than the females, though this slight variation has been previously documented by various authors (Bnetow, 1965; Behrman 1977). This higher prevalence in male may be adduced to exposure factors and peculiar behavioural attitudes/activities of them which make them more prone to accidents. This reason cannot be advanced to higher occurrence of neonatal septiceamia in males than females. Although no author has proffered any reason for this, it may be ascribed to genetic basis.

It is noteworthy that Gram positive organisms were more predominant than Gram negative ones. This is contrary to the earlier reports by Owa et al. (1988) at Wesley Guild Hospital, Ilesa, Alausa et al. 1984 at Ibadan and Dawodu et al. (1980) but conforms with those of Antia-Obong et al. (1990), Njokanma et al. (1990), Olusanya et al (1991) Ako-Nai et al. (1999) and Angyo et al. (2001). Of the Gram-positive bacteria, the three common microbes were $S$. aureus, $S$. albus and Streptococcus faecalis among which Staphylococcus aureus had the highest occurrence while Klebsiella sp. was the most predominant among the Gram negative bacteria, followed by $E$. coli and Pseudomonas sp. However, the four most common microbes isolated from blood cultures in this study were $S$. aureus, Klebsiella sp., E. coli and S. albus respectively in descending order. S. aureus was still the leading cause of Septicemia. This observation is in agreement with the work of some authors (Owa et al., 1988; Alausa et al., 1984; Olusanya et al., 1991; Ayliffe et al., 1977; Ako-Nai et al., 1999) but deviates from the reports from some hospitals from undeveloped countries by some authors. Gorbach and his colleagues (1992) reported that $E$. coli was the preponderant microbe. The occurrence of Klebsiella sp. in this study is in tandem with the findings of Olusanya et al. (1991), Ako-Nail et al. (1999) and Angyo et al. (2001) in Nigeria but at a wide variance with that of Ghanshyam et al (2002) in India. This work further revealed that there is drastic reduction in the incidence of septicaemia due to anaerobes in this $20^{\text {th }}$ century which is contrary to the report of several authors (Stoke, 1958) about four decades $19^{\text {th }}$ century. This observation was in similitudes of discovery of Mandell and colleagues (1995). The decline of detectable anaerobic septicaemia in many hospitals may be advanced to the wide spread use of antibiotics active against them especially in surgical prophylaxis. The significance of anaerobes in septicaemia has been explicitly demonstrated by Chow et al. (1994). The preponderance of facultative anaerobes in the blood cultures in this work which is completely in conformity with earlier reports of other authors (Shanson et al., 1999; Eugene et al., 1998) may be related to their defences and instrumentation and surgery. The other ability to live and survive in both anaerobic and anaerobic environment.

It has also been demonstrated in this study that most of the septicaemic episodes were caused by a single organism (Monomicrobe) while polymicrobial aetiology was observed in only a few cases. This observation is in consonance with earlier reports (Bartlett et al., 1974; Ghanshyam et al., 2002; Angyo et al., 2001). In Indian reports, polymicrobial aetiology was documented in $8 \%$ of cases by Thomas et al. (1999) and 6.8\% in another study by Ghanshyam et al. (2001) which are very similar to the incidence of $7.8 \%$ in this study. A western study reported an incidence of $3.9 \%$ of polymicrobial sepsis. Comparatively, this indicates that incidence of polymicrobial sepsis in developing countries is higher than in developed countries of the world. The decrease in incidence of septicaemia in developed countries may be due to proper sanitation which has successfully diminished the infection in more affluent regions of the world. Most clinical bacteriologists failed to report polymicrobial sepsis because of misconception of contamination, ignorance of its significance or disregard for the second organism in an already positive culture (Sharma et al., 1987; Mathur et al., 1994; Mondal et al., 1991). However, there is a need to correlate the occurrence of polymicrobial sepsis with clinical outcome in septicaemia. A patient already infected with one microbe may have acquired the second one from the hospital environment or both the bacteria could be nosocomial in origin.

A study of in vitro antimicrobial susceptibility profile of the aetiological agents of septicaemia has revealed that there is a growing emergence of multi-drug resistant microbes. Forty six percent $(46 \%)$ of $S$. aureus isolated were resistant to cloxacillin which is a drug often used for initial and empirical treatment of Staphylococcal infections. This high level of resistance to cloxacillin may pose problems in the treatment of staphylococcal septiceamia. The increasing resistance of $S$. aureus to cloxacillin, $46 \%$ observed as against $40 \%$ documented by Angyo et al. (2002) may be due to the widespread abuse of the drug which is usually available in combinations with ampicillin for the treatment of infections in our society and can be obtained over the counter without a prescription. About seventy to ninety percent $(70-90 \%)$ of $S$. aureus isolates were resistant to other commonly used antibiotics like penicillin, ampicllin, tetracyline and cotrimoxazole. The consequences of using an ineffective drug in severe bacterial infections could be disastrous as this can complicate management and increase morbidity and mortality. Nevertheless, it is interesting to observe that most of the organisms were sensitive to gentamycin, fortum, rocephin, zinnacef, peflacin and vancomycin respectively. Therefore, as gentamiyin and vancomycin are still effective, they can be prescribed for the initial and empirical treatment of septicaemia in our environment pending culture and sensitivity reports.

Although the sensitivity of the organism isolated to the third generation cephalosporin was generally 
excellent in the present study, the high cost of this group of drugs precludes their use as first choice in the treatment of septicaemia.

A general overview of the antibiogram of all the bacterial isolates indicates that Gram negative bacteria exhibited a greater level of antimicrobial susceptibility (ranging between 19.8\% - 92.3\%) than Gram positive bacteria $(10 \%-87 \%)$ to various antibacterial agents employed during the study period. This situation raises serious concern. This suggests a very high resistance gene pool due perhaps to gross misuse and inappropriate usage of the antibacterial agents.

The upsurge in the antibiotic resistance noticed in this study is in agreement with an earlier report by Obseiki-Ebor et al. 1987 where antibiotic abuse and high prevalence of self medication with antibiotics were identified as being responsible for the selection of antibiotic resistant bacterial strains. This piece of work has demonstrated vividly the urgent need for management strategies designed for specific groups of patients with infections in order to maximize therapeutic benefits, cost reduction and possible reduction in the incidence of adverse drug reactions. There is therefore need for usage policy that would be made applicable to the different tiers of our health care providers at the primary, secondary and tertiary levels. This can be done concurrently with sustained enlightenment and media publicity focusing attention on the dangers of high incidence of bacterial resistance to antibacterial agents in general and the ultimate consequences.

Finally, an assessment of the three traditional methods, namely visual inspection (Microscopy), Gram filming and culture for detecting positive blood culture has shown that the latter was the most sensitive, reliable and reproducible. Apart from the identification of the aetiological agents, the antibiogram can also be determined. It can detect some organisms that fail to produce sufficient turbidity to be detected by visual inspection at an early stage of incubation. It also facilitates the early diagnosis of polymicrobial infection and precise judgment/ruling out of suspected contamination of the specimen. Living bacteria could be isolated and distinguished from dead organism. The sensitivity of Gram stain is very close to that of macroscopic (visual) examination $(21.2 \%$ and $25.4 \%$ respectively). This is in tandem to results found by Freeman in 1990. Macroscopic and Gram filming could be adopted for use in rural laboratories that have no culture facilities. Both methods obviate the need for blind subculture and they might be employed as simple sensitive screening method for early detection of organisms in blood streams (Mirret et al., 1982).

\section{REFERENCES}

Ako-Nai, K., Adejuyigbe J., Ajayi, V. and Onipede M. (1999). The bacteriology of neonatal septicaemia in Ile-Ife, Nigeria. Journal of Tropical Paediatrics 45: $146-151$.
Akpede, G. O., Adeyemi O., and Ukwandu N. C. D. (1996). Burden and trends in the susceptibility of Staphylococcus aureus bacteraemia in hospitalised post-neonatal children in Maiduguri; 1991 - 95 Abstracts of proceedings of $27^{\text {th }}$ Annual General and Scientific Conference of the Paediatrics Association of Nigeria, Maiduguri, January 16-20; page 45.

Alausa, O. K. and Onile, B. A. (1984). The epidemiological pattern of bacterial septicaemia at University College Hospital, Ibadan. Nigeria Medical Journal 14: 55 - 62.

Angyo, I. A., Opkeh E. S. and Opajobi S. O. (2001). Predominant bacterial agents of childhood septicaemia in Jos. Nigerian Journal of Medicine 10: $75-77$.

Antia-Obong, O. E. and Utsalo, S. J. (1990) Bacterial agents in neonatal septicaemia in Calabar, Nigeria. Abstracts of proceedings, $21^{\text {st }}$ Annual Conference of the Paediatrics Association of Nigeria: page 35.

Ayliffe, G. A. J., Collins, B. J. and Taylor, I. J. (1997). Hospital-acquired infection: Principles and prevention, $3^{\text {rd }}$ edition page $45-50$ ButterworthHeinemann, Oxford.

Behrman, R. E. (1977). Postnatally acquired infections, $2^{\text {nd }}$ edition, page $286-292$. Mosby Publications.

Bennett, I. L. and Beeson, P. B. (1954). Bacteraemia: A consideration of some experimental and Clinical aspects. Yale Journal of Biology and Medicine 26: 241.

Bryant, J. K. and Strand C. L. (1987). Reliability of blood cultures collected from intravascular catheter versus venipuncture. American Journal of Clinical Pathology 88: 113 - 116.

Buetow, K. C., Wayne, K. and Lane, R. B. (1965). Septicaemia in premature infants. American Journal of Disease Children. 110: 29 - 40.

Chruickshank, R., Duguid, J. P., Marmoin, B. P. and Swain R. H. A. (1975). Significance of Coagulasenegative staphylococci and micrococci in clinical specimens. In Medical Microbiology volume two, pages $364-365,12^{\text {th }}$ edition, Church Hill Livingstone, Edinburgh London and New -York.

Dawodu, A. H. and Alausa, O. K. (1980). Neonatal septicaemia in the tropics. African Journal of Medical Science 21:1- 6 .

Douglas, J. S. and Morag, C. T. (1981). Septicaemia and endocarditis. In Notes on Medical Bacteriology, pages $238-245,1^{\text {st }}$ edition, Churchill Livingstone, Edinburgh, London, Melbourne and New-York.

Engene, W. N, Evans, C. R., Nancy, N. P, Denise, G. A. and Marthal, T. N. (1998). Bacterial Diseases of the Blood vascular system. In: Microbiology: A human perspective, pages $675-684,2^{\text {nd }}$ edition, Mc GrawHill, Boston.

Fischer, J., and Gottdenker, F. (1941). Transient Bacteraemia following tonsillectomy. Experimental bacteriological and clinical studies. Laryngoscope 51:271.

Ghanshyam, D. K., Ramachandram, V. C. and Piyush G. (2002). Bacteriological analysis of blood culture 
isolates from neonates in a tertiary care hospital in India. Journal Health Population Nutrition 20(4): 343 $-347$.

Gould, J. C. and Puerden, B. I. (1983). Blood culturecurrent state and future prospects. Journal of Clinical Pathology 36: 363 - 977.

Kulka, E. (1930). Veber Bakteriaemienei de normalen peride. Zentralbl. Gynak 54: 171.

Lambe, D. W., McPhedran, A. M., Mertz, J. A. and Stewart, P. (1973). Streptobacillus moniliformis isolated from a case of Haver-hill fever. American Journal of Clinical pathology 60: 854 - 860.

Mackie, T. J., McCartney, J. E., Collee, J. G., Duguid, J. P., Fraser, A. G. and Marrnoin, B. P. (1989). Laboratories strategy in the diagnosis of infective syndromes in Practical Medical Microbiology, pages 600-607, $13^{\text {th }}$ edition, Churchill Livingstone, Edinburgh and London.

Mandell, G. L., Bennett, J. E. and Dolan, R. (1995). Principles and practices of infectious diseases, pages $650-658,4^{\text {th }}$ edition, Churchill Livingstone, New York.

Mathur, M., Shah, H., Dixit, K., Khambdkone, S., Chakrapani, A. and Irani, S. (1994). Bacteriological profile of neonatal septicaemia cases (for the years 1990-91). Journal of Postgraduate Medicine 40: 18 20.

Mirrett, S., Lauer, B. A., Miller, G. A. and Reller, L. B. (1982). Comparison of acridine orange, methylene blue and Gram stains for blood cultures. Journal of Clinical Microbiology 15: 562 - 563.

Mondal, G. P., Ragharan, M., Bhat, B. V., Srinivasan, S. (1991). Neonatal septicaemia among in born and out born babies in a referral hospital. Indian Journal of Paediatrics 58: 529 - 533.

Murray, P. R. and Sonddag, J. E. (1978). Evaluation of routine subcultures of macroscopically negative blood cultures for detection of anaerobes. Journal of Clinical Microbiology 8: 427- 430.

Murray, M. and Moosnick (1941). Incidence of bacteraemia in patients with dental disease. Journal of Laboratory Clinical Medicine 26: 801.

Njokana, F. O., Okolo, A. A. and Omone, J. A. (1990). Neonatal septicaemia at the UBTH. Risk factors, bacterial infleuces and outcome. Abstracts of proceedings, $21^{\text {st }}$ Annual Conference of the Paediatric Association of Nigeria, page 33.

Obaseki-Ebor, E. E., Akerele, J. O., Ebea P. O. (1987). A survey of antibiotic self-medication. Journal of Antimicrobial chemistry 20(5): 759 - 763.

Olusanya, O., Olanrewaju, D. M., Ogunfowora, O. B. and Laditan, A. A. O. (1991). Neonatal septicaemia at the Ogun State University Teaching Hospital, Sagamu. Nigerian Medical Practitioner 22 (3): 39 42.

Owa, J. A. and Olusanya, O. (1988). Neonatal bacteriaemia in Wesley Guild Hospital Ilesa. Annal of Tropical Paediatrics 8:80 - 84.
Reller, C. K., Murray, P. and MacLowry, S. (1982). Blood Cultures. Cumitech IA, American Society of Microbiology, Washington, D.C page 1-6.

Roberton, N. R. C. (1986). A manual of neonatal intensive care, pages 167-169, $3^{\text {rd }}$ edition Butterworth Heinemann, Oxford and Aukland.

Shanson, D. C (1974). Comparison of two liquid blood culture media. Journal of Clinical Pathology 27: 273.

Shanson, D. C. (1999). Septicaemia. In: Microbiology in Clinical Practice, pages $110-118,3^{\text {rd }}$ edition, Butterworth Heinemann, Oxford and Aukland.

Shanson, D. C, Akash, S. and Harris, M. (1983). Clinical comparison of glucose broth with nutrient broth blood cultures for the detection of Streptococcus viridans bacteraemia. Journal of Medical Microbiology 16:497 - 499.

Sharma, P. P., Halder D., Dutta, A. K., Bhatnagar, S. and Bali A. et al. (1987). Bacteriological profile of neonatal septicaemia. Indian Journal Paediatrics 24: $101-117$.

Stokes, E.J., and Ridgway, G. and Wren, M.W.D. (1993). Clinical Microbiology, page $65-78,7^{\text {th }}$ edition, Edward, Arnold, London.

Stokes, E. J. and Ridgway, G. L. (1980). The culture of specimens normally sterile. In Clinical Bacteriology, pages $33-45,5^{\text {th }}$ edition, Edward Arnold Publication, Chicago. 